\title{
Impact of integrated package of agrotechniques on growth and yield of aerobic rice
}

\author{
C. M. Sunil`, B. C. Shankaralingappa \\ Department of Agronomy, University of Agricultural Sciences, Gandhi Krishi Vignana Kendra, Bengaluru, India; ${ }^{*}$ Corresponding \\ Author: sunilcmuasb@gmail.com
}

Received 21 November 2013; revised 21 December 2013; accepted 31 December 2013

Copyright (c) 2014 C. M. Sunil, B. C. Shankaralingappa. This is an open access article distributed under the Creative Commons Attribution License, which permits unrestricted use, distribution, and reproduction in any medium, provided the original work is properly cited. In accordance of the Creative Commons Attribution License all Copyrights (C) 2014 are reserved for SCIRP and the owner of the intellectual property C. M. Sunil, B. C. Shankaralingappa. All Copyright (C) 2014 are guarded by law and by SCIRP as a guardian.

\section{ABSTRACT}

A field experiment was conducted during Kharif, 2011-2012 and 2012-2013 at GKVK, Bengaluru, Karnataka to study the effect of integrated package of agrotechniques on growth and yield of aerobic rice. The predominant weed flora observed in the experimental field were, Eleusine indica, Digitaria marginata L., Dactyloctenium aegyptium L., Alternanthera sessilis, Mollugo distica L., Celosia argentia and Borreria hispida. Treatments receiving integrated weed management practices recorded significantly lower weed population and weed dry weight as compared to pre-emergence application of pyrazosulfuron ethyl alone. Application of RDF + $\mathrm{FYM}+$ Biofertilizers + $\mathrm{FeSO}_{4}+\mathrm{IWM}$ practices $\left(\mathrm{T}_{8}\right)$ recorded significantly higher growth, yield parameters and yield as compared to RDF + FYM + IWM practices and was being on par with RDF + FYM + Biofertilizers + IWM practices.

\section{KEYWORDS}

\section{Aerobic Rice; Integrated Agrotechniques; Intercultivation; Weed Management}

\section{INTRODUCTION}

Water shortage is becoming severe in many ricegrowing areas in the world. The introduction of aerobic rice means growing of high yielding rice in non-puddled and non-flooded aerobic soil with the support of external inputs like supplementary irrigation, manures and fertilizers, through which 30 - 50 per cent of water can be saved [1]. However, weeds are the greatest constraint in aerobic rice system, resulting in 30 - 98 per cent yield losses [2]. Since the crop is sown in nonpuddled, unflooded soil in aerobic rice, the weeds and rice germinate simultaneously. The absence of standing water makes aerobic rice more weed infested resulting in competition for resources with crop plants. In this contrast, usage of herbicides is proven to be more effective but intensive herbicide use can cause environmental contamination and the development of herbicide resistance by weeds [3]. Hence use of herbicide along with hand weeding and intercultivation is proven to be better in controlling weeds.

Shifting from submerged rice to aerobic system of rice cultivation has led to changes in soil physical, chemical and biological properties resulting in iron deficiency [4]. Further limited use of organics and absence of proper recycling of crop residues also added to deficiencies under this system of rice cultivation. The biofertilizers, being alternative low-cost plant nutrient resources have gained prime importance in recent decades and they play a vital role in maintaining long term soil fertility sustenance. The site specific nutrient management (SSNM) is a repacking of management concepts. The SSNM avoids indiscriminate use of nutrients by preventing excessive and/or inadequate nutrient inputs and helps to maintain soil health over a long period of time. The productivity of aerobic rice is equal to or less than that of submerged rice but the water requirement of aerobic rice is about 50 - 70 per cent of submerged rice [5]. The research information on integration of all available technologies in aerobic rice production is lacking. Keeping these points in view, an experiment entitled growth, yield and economics of aerobic rice as influenced by integrated package of agrotechniques was conducted.

\section{MATERIALS AND METHODS}

A field experiment was conducted from 2011-2012 to 
2012-2013 at Zonal Agricultural research station, GKVK, Bengaluru, Karnataka which is located in the Eastern Dry Zone of Karnataka at $12^{\circ} 58^{\prime}$ North latitude, $77^{\circ} 35^{\prime}$ East longitude with an altitude of $930 \mathrm{~m}$ above the mean sea level. The soil of the experimental site was red sandy loamy in texture and $\mathrm{pH}$ was neutral. The soil was medium in available nitrogen, phosphorus and potassium. The organic carbon content was low in range (Table 1). The normal as well as actual weather conditions such as rainfall, temperature (maximum and minimum), relative humidity, daily bright sunshine hours and open pan eva- poration prevailed during the crop growth period of 2011 \& 2012 are presented in Figures 1(a) and (b).

MAS-26 a popular Semi dwarf, medium duration and deep rooted aerobic rice variety developed by using Marker Assisted Selection at University of Agricultural Sciences, Bengaluru was sown in July with a spacing of $30 \mathrm{~cm} \times 30 \mathrm{~cm}$. All the plots were irrigated with a depth of $5 \mathrm{~cm}$ immediately after sowing and subsequent irrigations were given with a depth of $4 \mathrm{~cm}$ at 5 days interval during vegetative growth stage followed by 3 days interval during reproductive growth stage of the crop Farm

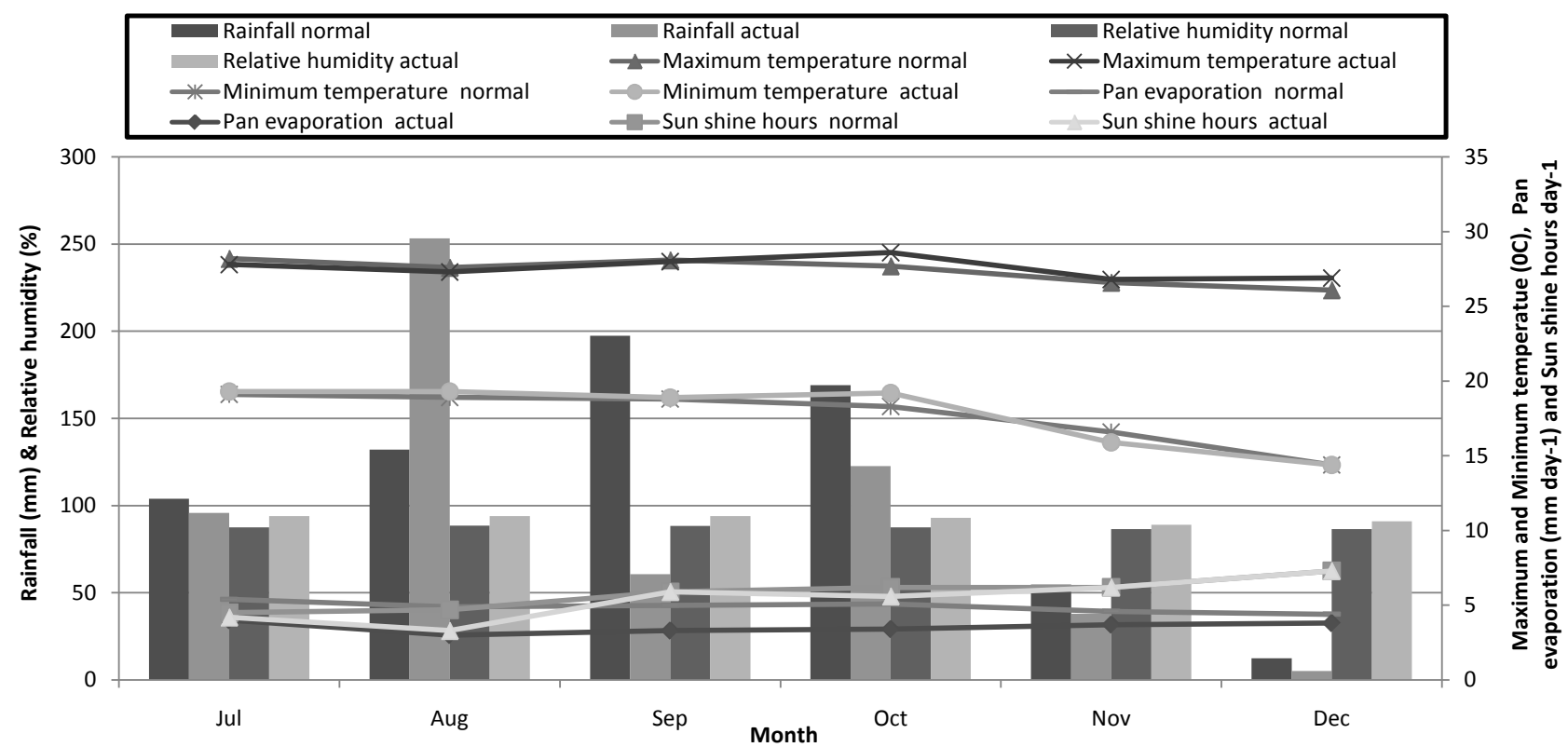

(a)

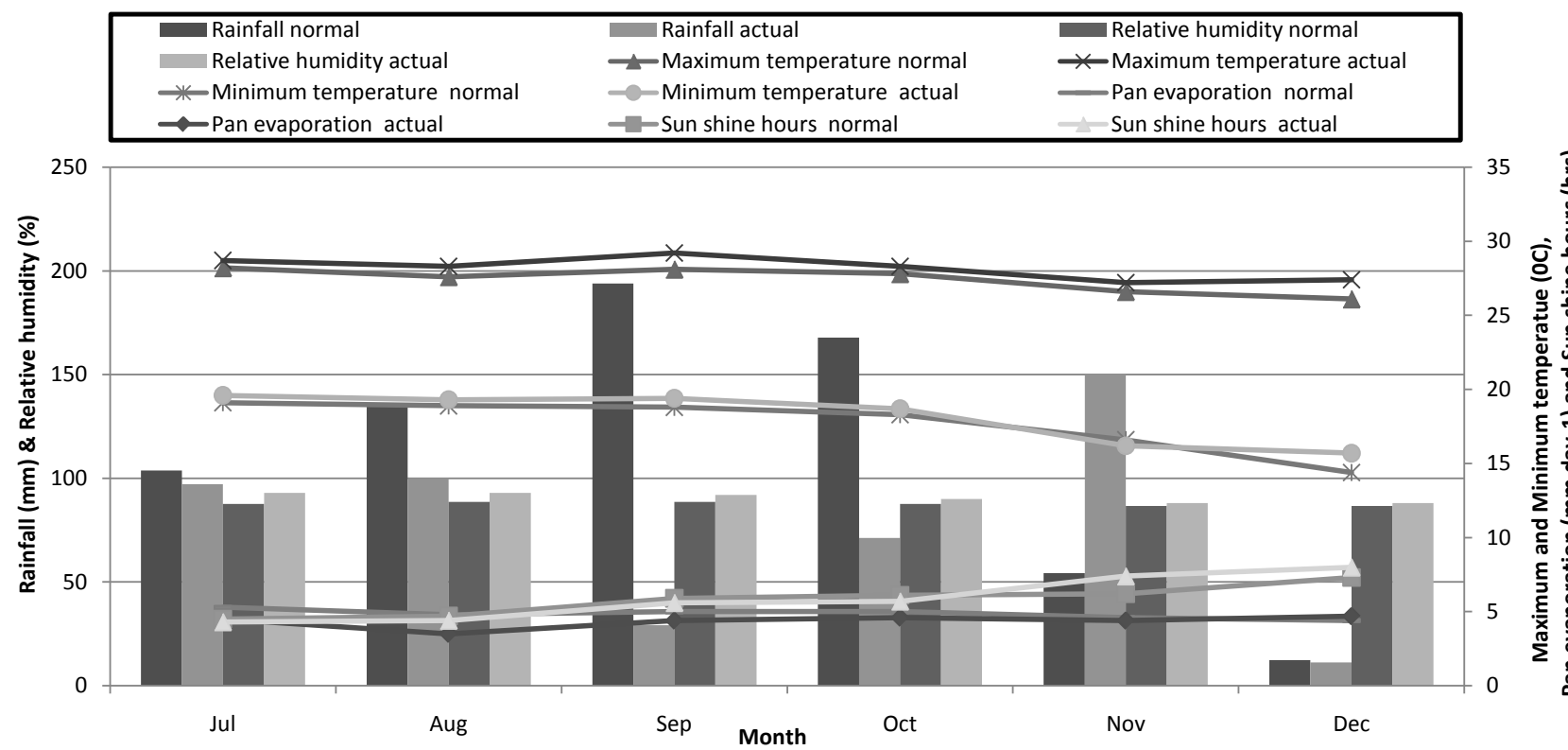

(b)

Figure 1. (a) Mean monthly weather data during the crop growth period at ZARS, GKVK, Bengaluru, 2011; (b) Mean monthly weather data during the crop growth period at ZARS, GKVK, Bengaluru, 2012. 
Table 1. Physical and chemical properties of the soil in the experimental field during kharif, 2011 and 2012.

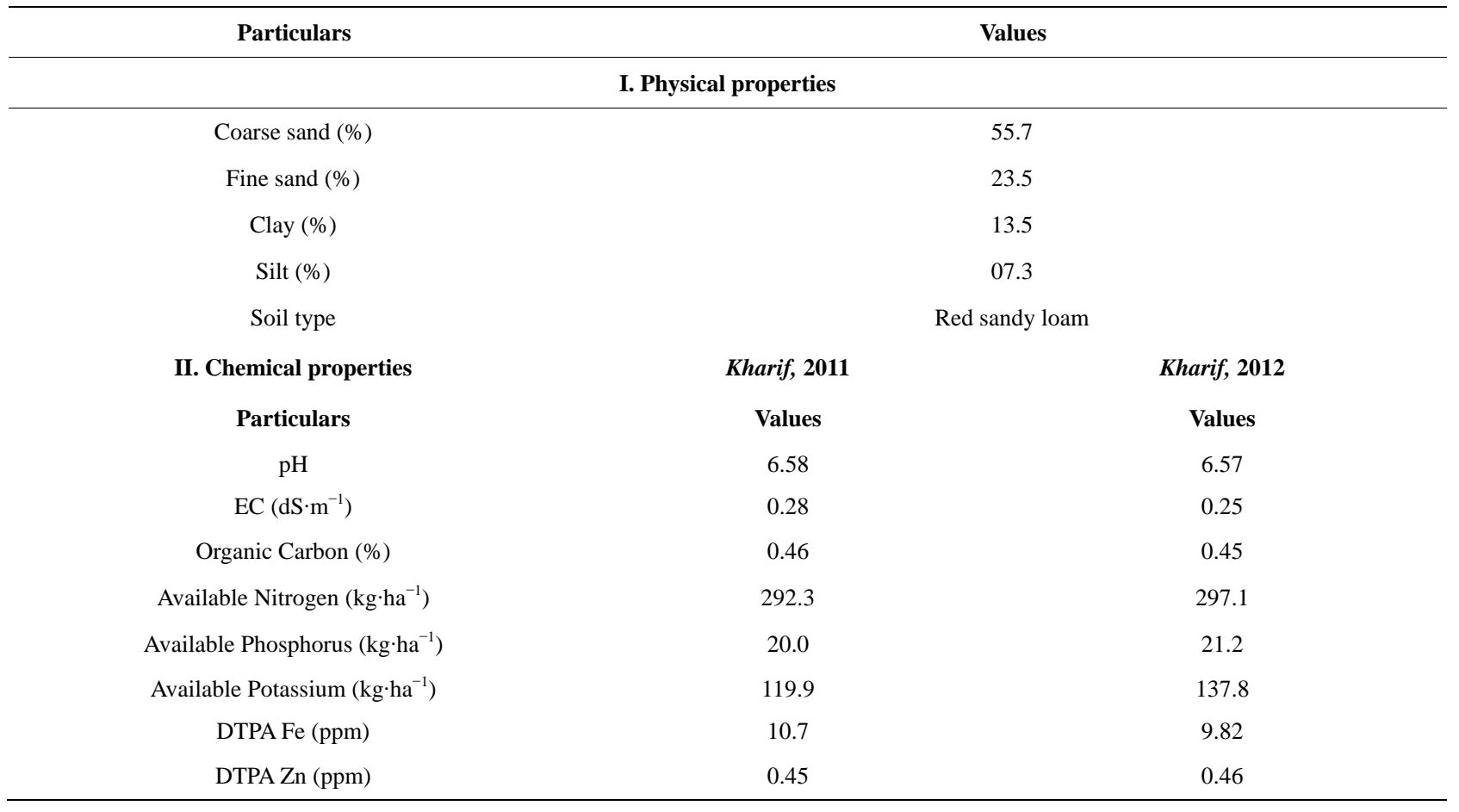

yard manure was applied at the rate of $10 \mathrm{t} \cdot \mathrm{ha}^{-1}$ to each plot three weeks prior to sowing. A common dose of fertilizer was applied at the rate of $50 \mathrm{~kg}$ of $\mathrm{N}, 50 \mathrm{~kg}$ of $\mathrm{P}$, $50 \mathrm{~kg}$ of $\mathrm{K}$ and $20 \mathrm{~kg}$ of $\mathrm{ZnSO}_{4} \mathrm{ha}^{-1}$ as basal dose at the time of sowing in the form of urea, single super phosphate, muriate of potash and zinc sulphate, respectively. The remaining $50 \mathrm{~kg}$ nitrogen was applied in two equal splits each at 30 and 60 days after sowing in the form of urea to the treatments. Iron as $\mathrm{FeSO}_{4}$ at $12.5 \mathrm{~kg} \cdot \mathrm{ha}^{-1}$, Azospirillum and PSB (Bacillus megaterium) at $4 \mathrm{~kg}$ each ha ${ }^{-1}$ mixed with $80 \mathrm{~kg}$ of farm yard manure were applied as per the treatments. In site specific nutrient management for targeted yield of $6.5 \mathrm{t} \cdot \mathrm{ha}^{-1}$ 130:32:162 $\mathrm{kg} \mathrm{N}, \mathrm{P}$ and $\mathrm{K} \cdot \mathrm{ha}^{-1}$ and for targeted yield of $7.5 \mathrm{t} \cdot \mathrm{ha}^{-1}$ 150:37:187 kg N, P and $\mathrm{K} \mathrm{ha}^{-1}$ was applied. Irrigation was stopped a week prior to harvest of the crop. Experiment included ten treatments consisted of $\mathbf{T}_{1}$ : RDF $\left(100: 50: 50: 20 \mathrm{~kg}\right.$ NPK and $\left.\mathrm{ZnSO}_{4} \mathrm{ha}^{-1}\right)+\mathrm{FYM}$ at $10 \mathrm{t}$ $\mathrm{ha}^{-1}+$ Pyrazosulfuron ethyl at $25 \mathrm{~g} \cdot \mathrm{a} \cdot \mathrm{i} \cdot \mathrm{ha}{ }^{-1} ; \mathbf{T}_{2}$ : RDF + $\mathrm{FYM}+\mathrm{FeSO}_{4}$ at $12.5 \mathrm{~kg} \cdot \mathrm{ha}^{-1}+$ Pyrazosulfuron ethyl at 25 g.a.i ha $^{-1} ; \mathbf{T}_{3}: \mathrm{RDF}+\mathrm{FYM}+$ Biofertilizers + Pyrazosulfuron ethyl at $25 \mathrm{~g} \cdot \mathrm{a} . \mathrm{i} \cdot \mathrm{ha}^{-1} ; \mathbf{T}_{4}$ : RDF + FYM + Biofertilizers $+\mathrm{FeSO}_{4}+$ Pyrazosulfuron ethyl at $25 \mathrm{~g} \cdot \mathrm{a} . \mathrm{i} \cdot \mathrm{ha}^{-1}$; $\mathbf{T}_{5}$ : RDF + FYM + Integrated weed management practices (Pre-emergence application of pyrazosulfuron ethyl at $25 \mathrm{~g} \cdot \mathrm{a} \cdot \mathrm{i} \cdot \mathrm{ha}^{-1}+$ One hand weeding at 20 days after sowing + First intercultivation at 25 days after sowing and subsequent intercultivations at 15 days interval upto panicle initiation); $\mathbf{T}_{6}: \mathrm{RDF}+\mathrm{FYM}+\mathrm{FeSO}_{4}+$ Integrated weed management practices; $\mathbf{T}_{7}$ : RDF + FYM + Biofer- tilizers + Integrated weed management practices; $\mathbf{T}_{\mathbf{8}}$ : $\mathrm{RDF}+\mathrm{FYM}+$ Biofertilizers $+\mathrm{FeSO}_{4}+$ Integrated weed management practices; $\mathbf{T}_{\mathbf{9}}$ : Site specific nutrient management (SSNM) for targeted yield of $6.5 \mathrm{t} \cdot \mathrm{ha}^{-1}+$ Integrated weed management practices (IWMP); $\mathbf{T}_{\mathbf{1 0}}$ : Site specific nutrient management (SSNM) for targeted yield of $7.5 \mathrm{t}^{\mathrm{a}} \mathrm{h}^{-1}+$ Integrated weed management practices (IWMP) were laid out in Randomized Complete Block Design (RCBD) with three replications. Pre-emergence application of herbicides was done at three day after sowing. Since the data on weed count and weed dry weight showed high variation the data was subjected to square root transformation using the formula $\sqrt{\mathrm{x}}+0.5$ and the statistical analysis was done. The following growth parameters viz. Plant height in centimeter $(\mathrm{cm})$, Number of tillers per hill, Leaf area index, Dry matter production in grams (g), yield parameters viz. Productive tillers per hill, Panicle length (cm), Weight of panicle (g), Number of filled grains, 1000 grain weight, Grain yield hill $^{-1}$, Straw yield hill ${ }^{-1}$ and grain yield and straw yield per hectare were recorded. The response of aerobic rice to integrated package of agrotechniques was similar in both the years of study. Therefore, only pooled data of two years is discussed.

\section{RESULTS AND DISCUSSION}

\subsection{Effect on Weeds}

The predominant weed flora observed in the experimental field during kharif, 2011 and 2012 in association 
with the aerobic rice were narrow leaved weeds such as Eleusine indica, Digitaria marginata L., Dactyloctenium aegyptium L., Rhynchelytrum repens and broad leaved weeds like Alternanthera sessilis, Euphorbia geniculata L., Mollugo distica L., Celosia argentia, Emilia sonchifolia, Phyllanthus niruri, Borreria hispida and Spilanthes acmella [6,7].

Treatments receiving integrated weed management practices recorded significantly lower weed population (21.67 - $31.50 \mathrm{~m}^{-2}$ ) and weed dry weight (5.29 - 8.89 $\mathrm{g} \cdot \mathrm{m}^{-2}$ ) as compared to pre-emergence application of pyrazosulfuron ethyl alone $\left(61.0-66.33 \mathrm{~m}^{-2}\right.$ and $24.83-$ $28.43 \mathrm{~g} \cdot \mathrm{m}^{-2}$, respectively) (Table 2 ).

\subsection{Effect on Crop Growth}

Application of RDF+ FYM + Biofertilizers $+\mathrm{FeSO}_{4}+$ IWM practices recorded significantly higher plant height, number of tillers per hill, leaf area index at 90 days after sowing (DAS) and higher dry matter production as compared to RDF+ FYM + IWM practices and SSNM + IWM practices and was on par RDF + FYM + Biofertilizers + IWM practices (Table 3). This might be due to better weed control, application of biofertilizers along with zinc and iron enhanced the $\mathrm{N}$ fixation, phytohormone production, increased $\mathrm{Zn}$ absorption in plants and also enhanced the phosphate and iron solubilization by the production of organic acids resulted in better growth parameters $[8,9]$.

\subsection{Effect on Yield and Yield Parameters}

The yield parameters viz., productive tillers per hill, panicle length, weight of panicle, number of filled grains, 1000 grain weight and grain yield per hill were significantly higher with RDF+ FYM + Biofertilizers $+\mathrm{FeSO}_{4}$ + IWM practices as compared to RDF+ FYM + IWM practices and SSNM + IWM practices and was on par with RDF + FYM + Biofertilizers + Integrated weed management practices (Tables 4 and 5). This was mainly due to better growth parameters $[10,11]$.

No yield was harvested in the treatments $\left(T_{1}\right.$ to $\left.T_{4}\right)$ receiving pre-emergence application of pyrazosulfuron ethyl at $25 \mathrm{~g} \cdot \mathrm{a} \cdot \mathrm{i} \cdot \mathrm{ha}^{-1}$ without IWM practices since the aerobic rice completely failed due to significantly higher weed density and weed dry weight indicating that preemergence application of pyrazosulfuron ethyl alone was not able to control weeds particularly Eleusine indica under aerobic conditions because it has developed resistance against this Aceto lactate synthesis inhibitor [12].

Application of RDF+ FYM + Biofertilizers $+\mathrm{FeSO}_{4}+$ Integrated weed management practices being on par with

Table 2. Weed count and weed dry weight in aerobic rice as influenced by integrated package of agrotechniques (Pooled data of 2 years).

\begin{tabular}{|c|c|c|c|c|c|c|}
\hline \multirow{2}{*}{ Treatments } & \multicolumn{3}{|c|}{ Weed count $\mathbf{m}^{2}$} & \multicolumn{3}{|c|}{ Weed dry weight $\left(g \cdot \mathbf{m}^{2}\right)$} \\
\hline & Narrow leaved & Broad leaved & Total & Narrow leaved & Broad leaved & Total \\
\hline $\begin{array}{c}\mathbf{T}_{2}: \mathrm{RDF}+\mathrm{FYM}+\mathrm{FeSO}_{4}+ \\
\text { Pyrazosulfuron ethyl at } 25 \mathrm{~g} \cdot \mathrm{a} \cdot \mathrm{i} \cdot \mathrm{ha}^{-1}\end{array}$ & $6.15(37.50)$ & $5.40(28.67)$ & $8.16(66.17)$ & 4.88 (23.29) & $2.00(3.52)$ & $5.22(26.81)$ \\
\hline $\begin{array}{l}\mathbf{T}_{3}: \text { RDF }+ \text { FYM + Biofertilizers }+ \\
\text { Pyrazosulfuron ethyl at } 25 \mathrm{~g} \cdot \mathrm{a.i}^{+} \cdot \mathrm{ha}^{-1}\end{array}$ & $6.01(35.83)$ & $5.43(29.10)$ & $8.08(64.83)$ & $4.96(24.13)$ & 1.99 (3.47) & $5.30(27.60)$ \\
\hline $\begin{array}{c}\mathbf{T}_{4}: \text { RDF + FYM + Biofertilizers }+\mathrm{FeSO}_{4}+ \\
\text { Pyrazosulfuron ethyl at } 25 \mathrm{~g} \cdot \mathrm{a} \cdot \mathrm{i} \cdot \mathrm{ha}^{-1}\end{array}$ & $5.79(33.33)$ & $5.30(27.67)$ & $7.83(61.00)$ & $4.67(21.45)$ & 1.97 (3.39) & $5.02(24.83)$ \\
\hline $\mathbf{T}_{5}: \mathrm{RDF}+\mathrm{FYM}+\mathrm{IWMP}$ & $3.36(11.00)$ & $4.43(19.83)$ & $5.53(30.83)$ & $2.55(6.16)$ & $1.68(2.47)$ & $3.02(8.63)$ \\
\hline $\mathbf{T}_{7}:$ RDF + FYM + Biofertilizers + IWMP & 3.02 (8.67) & $4.22(17.67)$ & $5.15(26.33)$ & $2.24(4.87)$ & 1.55 (1.97) & $2.68(6.84)$ \\
\hline $\mathbf{T}_{8}: \mathrm{RDF}+\mathrm{FYM}+$ Biofertilizers $+\mathrm{FeSO}_{4}+\mathrm{IWMP}$ & $2.61(6.33)$ & 3.95 (15.33) & 4.69 (21.67) & $1.92(3.46)$ & $1.51(1.82)$ & $2.39(5.29)$ \\
\hline $\begin{array}{l}\mathbf{T}_{9} \text { : Site specific nutrient management (SSNM) } \\
\text { for targeted yield of } 6.5 \mathrm{t} \cdot \mathrm{ha}^{-1}+\text { IWMP }\end{array}$ & 3.38 (11.17) & $4.47(20.00)$ & $5.60(31.17)$ & $2.53(6.14)$ & $1.77(2.72)$ & $3.05(8.86)$ \\
\hline $\begin{array}{l}\mathbf{T}_{\mathbf{1 0}} \text { : Site specific nutrient management (SSNM) } \\
\text { for targeted yield of } 7.5 \mathrm{t} \cdot \mathrm{ha}^{-1}+\text { IWMP }\end{array}$ & 3.37 (11.00) & $4.53(20.50)$ & $5.60(31.50)$ & $2.50(5.80)$ & $1.86(3.09)$ & $3.06(8.89)$ \\
\hline S. Em. \pm & 0.16 & 0.13 & 0.16 & 0.14 & 0.05 & 0.10 \\
\hline C.D. $(P=0.05)$ & 0.44 & 0.39 & 0.47 & 0.43 & 0.14 & 0.31 \\
\hline
\end{tabular}

Note: Original values are in parentheses. 
Table 3. Effect of integrated package of agrotechniques on growth parameters of aerobic rice (Pooled data of 2 years).

\begin{tabular}{|c|c|c|c|c|}
\hline Treatments & Plant height $(\mathbf{c m})$ & Number of tillers per hill & Leaf area index & 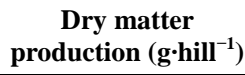 \\
\hline $\mathbf{T}_{5}:$ RDF + FYM + IWM practices & 49.9 & 29.0 & 1.950 & 65.19 \\
\hline $\mathbf{T}_{6}: \mathrm{RDF}+\mathrm{FYM}+\mathrm{FeSO}_{4}+$ IWM practices & 51.7 & 29.6 & 2.009 & 68.07 \\
\hline $\mathbf{T}_{7}:$ RDF + FYM + Biofertilizers + IWM practices & 55.4 & 33.4 & 2.211 & 75.55 \\
\hline $\mathbf{T}_{8}: \mathrm{RDF}+\mathrm{FYM}+$ Biofertilizers $+\mathrm{FeSO}_{4}+$ practices & 59.0 & 35.9 & 2.512 & 80.75 \\
\hline $\begin{array}{l}\mathbf{T}_{9} \text { :Site specific nutrient management (SSNM) } \\
\text { for targeted yield of } 6.5 \mathrm{t}^{-h^{-1}}+\text { IWMP }\end{array}$ & 50.7 & 30.1 & 1.892 & 67.99 \\
\hline $\begin{array}{l}\mathbf{T}_{\mathbf{1 0}} \text { :Site specific nutrient management (SSNM) } \\
\text { for targeted yield of } 7.5 \mathrm{t} \cdot \mathrm{ha}^{-1}+\text { IWMP }\end{array}$ & 49.5 & 29.0 & 1.815 & 64.53 \\
\hline S. Em. \pm & 1.56 & 1.0 & 0.096 & 1.86 \\
\hline C.D. $(P=0.05)$ & 4.62 & 2.9 & 0.310 & 5.53 \\
\hline
\end{tabular}

Note: Aerobic rice in treatments receiving pre-emergence application of pyrazosulfuron ethyl alone (without IWMP) ( $\mathrm{T}_{1}$ to $\mathrm{T}_{4}$ ) experienced severe weed competition resulting in complete death of all rice plants Statistical analysis therefore was done for only six treatments $\left(T_{5}\right.$ to $\left.T_{10}\right)$ by leaving first four treatments $\left(T_{1}\right.$ to $\left.\mathrm{T}_{4}\right)$.

Table 4. Effect of integrated package of agrotechniques on yield parameters of aerobic rice (Pooled data of 2 years).

\begin{tabular}{|c|c|c|c|c|c|}
\hline Treatments & $\begin{array}{l}\text { Productive tillers } \\
\text { per hill }\end{array}$ & $\begin{array}{l}\text { Panicle length } \\
\text { (cm) }\end{array}$ & $\begin{array}{l}\text { Weight of } \\
\text { panicle (g) }\end{array}$ & $\begin{array}{l}\text { Number of } \\
\text { filled grains }\end{array}$ & $\begin{array}{l}1000 \text { grain } \\
\text { weight (g) }\end{array}$ \\
\hline $\mathbf{T}_{5}: \mathrm{RDF}+\mathrm{FYM}+\mathrm{IWM}$ practices & 23.8 & 20.9 & 2.65 & 89.2 & 22.85 \\
\hline $\mathbf{T}_{6}: \mathrm{RDF}+\mathrm{FYM}+\mathrm{FeSO}_{4}+$ IWM practices & 24.4 & 21.1 & 2.75 & 90.1 & 23.20 \\
\hline $\mathbf{T}_{7}: \mathrm{RDF}+\mathrm{FYM}+$ Biofertilizers + IWM practices & 27.9 & 21.8 & 2.89 & 101.6 & 24.82 \\
\hline $\mathbf{T}_{8}: \mathrm{RDF}+\mathrm{FYM}+$ Biofertilizers $+\mathrm{FeSO}_{4}+$ practices & 30.7 & 23.0 & 2.98 & 108.4 & 25.61 \\
\hline $\begin{array}{c}\mathbf{T}_{9}: \text { Site specific nutrient management (SSNM) for targeted } \\
\text { yield of } 6.5 \mathrm{t} \cdot \mathrm{ha}^{-1}+\text { IWMP }\end{array}$ & 24.8 & 21.2 & 2.76 & 90.9 & 23.07 \\
\hline $\begin{array}{c}\mathbf{T}_{\mathbf{1 0}} \text { :Site specific nutrient management (SSNM) for targeted } \\
\text { yield of } 7.5 \mathrm{t} \cdot \mathrm{ha}^{-1}+\text { IWMP }\end{array}$ & 24.2 & 21.0 & 2.74 & 88.8 & 23.01 \\
\hline S. Em. \pm & 1.00 & 0.42 & 0.05 & 2.7 & 0.35 \\
\hline C.D. $(P=0.05)$ & 2.96 & 1.25 & 0.15 & 8.1 & 1.05 \\
\hline
\end{tabular}

Note: Aerobic rice in treatments receiving pre-emergence application of pyrazosulfuron ethyl alone (without IWMP) ( $\mathrm{T}_{1}$ to $\mathrm{T}_{4}$ ) experienced severe weed competition resulting in complete death of all rice plants Statistical analysis therefore was done for only six treatments $\left(T_{5}\right.$ to $\left.T_{10}\right)$ by leaving first four treatments $\left(T_{1}\right.$ to $\left.\mathrm{T}_{4}\right)$.

Table 5. Effect of integrated package of agrotechniques on grain and straw yield of aerobic rice (Pooled data of 2 years).

\begin{tabular}{|c|c|c|c|c|}
\hline Treatments & Grain yield hill $^{-1}$ & Straw yield hill ${ }^{-1}$ & Grain yield $\left(\mathrm{kg} \cdot \mathrm{ha}^{-1}\right)$ & Straw yield $\left(\mathbf{k g} \cdot \mathrm{ha}^{-1}\right)$ \\
\hline $\mathbf{T}_{5}:$ RDF + FYM + IWM practices & 33.05 & 35.16 & 3053 & 4261 \\
\hline $\mathbf{T}_{6}: \mathrm{RDF}+\mathrm{FYM}+\mathrm{FeSO}_{4}+$ IWM practices & 33.92 & 36.77 & 3213 & 4417 \\
\hline $\mathbf{T}_{7}:$ RDF + FYM + Biofertilizers + IWM practices & 37.98 & 40.97 & 3479 & 4685 \\
\hline $\mathbf{T}_{8}: \mathrm{RDF}+\mathrm{FYM}+$ Biofertilizers $+\mathrm{FeSO}_{4}+$ practices & 41.57 & 43.20 & 3880 & 5047 \\
\hline $\begin{array}{c}\mathbf{T}_{9} \text { :Site specific nutrient management (SSNM) for targeted } \\
\text { yield of } 6.5 \mathrm{t} \cdot \mathrm{ha}^{-1}+\text { IWMP }\end{array}$ & 32.59 & 36.94 & 3263 & 4414 \\
\hline $\begin{array}{c}\mathbf{T}_{10} \text { :Site specific nutrient management (SSNM) for targeted } \\
\text { yield of } 7.5 \mathrm{t} \cdot \mathrm{ha}^{-1}+\text { IWMP }\end{array}$ & 30.57 & 34.97 & 3086 & 4246 \\
\hline S. Em. \pm & 1.12 & 1.04 & 142 & 127 \\
\hline C.D. $(P=0.05)$ & 3.67 & 3.08 & 423 & 389 \\
\hline
\end{tabular}

Note: Aerobic rice in treatments receiving pre emergence application of pyrazosulfuron ethyl alone (without IWMP) (T $\mathrm{T}_{1}$ to $\left.\mathrm{T}_{4}\right)$ experienced severe weed competition resulting in complete death of all rice plants Statistical analysis therefore was done for only six treatments $\left(T_{5}\right.$ to $\left.T_{10}\right)$ by leaving first four treatments ( $T_{1}$ to $\mathrm{T}_{4}$ ). 
RDF + FYM + Biofertilizers + IWM practices recorded significantly $27.1 \%$ and $18.9 \%$ to $25.7 \%$ higher grain yield as compared to RDF+ FYM + Integrated weed management practices and SSNM + Integrated weed management practices. Similar trend was also been observed with straw yield (Table 5) [7,13].

\section{CONCLUSION}

Application of RDF+ FYM + Biofertilizers $+\mathrm{FeSO}_{4}+$ IWM practices resulted in effective weed control, and better growth and yield parameters in turn produced higher grain yield and straw yield of aerobic rice.

\section{ACKNOWLEDGEMENT}

My sincere thanks to Department of Science and Technology, New Delhi, Government of India for providing me financial support for conducting the research in the form of Innovation in Science Pursuit for Inspired Research (INSPIRE) Fellowship.

\section{REFERENCES}

[1] Shekara, B.G., Nagaraju, A.N.D. and Shreedhara, D. (2010) Growth and yield of aerobic rice (Oryza sativa L.) as influenced by different levels of NPK in Cauvery command area. Journal of Maharashtra Agricultural Universities, 35, 195-198.

[2] Mishra, J.S. and Singh, V.P. (2007) Integrated weed management in zero till direct seeded rice (Oryza sativa L.)-Wheat (Triticum aestivum) cropping system. Indian Journal of Agronomy, 52, 198-203.

[3] Fischer, A.J., Ramirez, H., Gibson, K.D. and Pinheiro, B.D.S. (2001) Competitiveness of semi dwarf upland rice cultivars against palisade grass (Brachiaria brizantha) and signal grass (B. decumbens). Agronomy Journal, 93, 967-973. http://dx.doi.org/10.2134/agronj2001.935967x

[4] Kanwar, L.S. (2012) Soil fertility in flooded and nonflooded irrigated rice systems. Archives of Agronomy and Soil Science, 58, 423-436. http://dx.doi.org/10.1080/03650340.2010.522993

[5] Suryavanshi, P., Jitesh, B. and Babu, S. (2012) Aerobic rice, a new approach of rice cultivation. International Research Journal of Biological Sciences, 1, 1-6.

[6] Chauhan, B.S. and Johnson, D.E. (2011) Row spacing and weed control timing affect yield of aerobic rice. Field Crops Research, 121, 226-231. http://dx.doi.org/10.1016/j.fcr.2010.12.008

[7] Jayadeva, H.M., Bhairappanavar, S.T., Hugar, A.Y., Rangaswamy, B.R., Mallikarjun, G.B., Malleshappa, C. and Channa Naik, D. (2011) Integrated weed management in aerobic rice (Oryza sativa). Agricultural Science Digest, 31, 58-61.

[8] Chinnusamy, M., Kaushik, B.D. and Prasanna, R. (2006) Growth, nutritional, and yield parameters of wetland rice as influenced by microbial consortia under controlled conditions. Journal of Plant Nutrition, 29, 857-871. http://dx.doi.org/10.1080/01904160600651803

[9] Davis, W.B. and Byer, B.R. (1971) Active transport of iron in Bacillus megaterium: Role of secondary hydroxamic acids. Journal of Bacteriology, 107, 491-498.

[10] Raja, P., Uma, S., Gopal, H. and Govindarajan, K. (2006) Impact of bio inoculants consortium on rice root exudates, biological nitrogen fixation and plant growth. Journal of Biological Sciences, 6, 815-823. http://dx.doi.org/10.3923/jbs.2006.815.823

[11] Yogesh, T.C. (2009) Response of aerobic paddy to integrated micronutrients (Fe\&Zn) management. M.Sc. (Agri.) Thesis, University of Agricultural Sciences, GKVK, Bengaluru.

[12] Heap, I.M. (2002) International survey of herbicide resistance weeds. Www.weedscience.com

[13] Police Patil, A.S. (2011) Yield maximization in aerobic rice through site specific nutrient management approach. $\mathrm{Ph}$. D. Thesis, University of Agricultural Sciences, Gandhi Krishi Vignana Kendra, Bangalore. 